\title{
PENGENALAN ANALISIS KELAYAKAN USAHA TANI PADI SAWAH DI DESA KEBUN KELAPA KECAMATAN SECANGGANG KABUPATEN LANGKAT
}

\author{
Endang Sari Simanullang ${ }^{1 *}$, Faoeza Hafiz Saragih ${ }^{1}$ \\ ${ }^{1}$ Program Studi Agribisnis, Fakultas Pertanian, Universitas Medan Area, \\ Jl. Kolam No. 1 Medan Estate - Medan 20223 \\ Penulis Korespodensi : ensa1939@gmail.com
}

\begin{abstract}
Abstrak
Kegiatan Pengabdian kepada Masyarakat telah dilaksanakan pada hari kamis tanggal 22 oktober 2015 di Desa Kebun Kelapa Kecamatan Secanggang Kabupaten Langkat dengan metode ceramah dan diskusi dengan mitra kelompok tani "Suka Tani". Mitra kelompok tani "Suka Tani" berpartisipasi aktif dalam mengikuti pelatihan dalam kegiatan Pengabdian kepada Masyarakat dan mengharapkan tindak lanjut kegiatan Pengabdian kepada Masyarakat dalam kegiatan selanjutnya untuk pengembangan usahatani padi sawah mitra kelompok tani "Suka Tani". Mitra kelompok tani "Suka Tani" dapat mengevaluasi kelayakan usahatani padi sawah melalui analisis kelayakan usahatani, apabila kelayakan usahatani padi sawah yang dikembangkan oleh mitra kelompok tani "Suka Tani" tidak layak untuk dikembangkan, maka mitra kelompok tani 'Suka Tani" dapat mengusahakan peluang bisnis penangkaran benih padi sawah sebagai alternatif peluang bisnis dan pembinaan mitra kelompok tani "Suka Tani" melalui kegiatan Pengabdian kepada Masyarakat akan dilanjutkan dalam kegiatan selanjutnya mengenai pengenalan peluang bisnis penangkaran benih padi sawah.
\end{abstract}

Kata kunci : Kelayakan, Pengembangan Masyarakat, Padi

\begin{abstract}
Community Development Programme was held on Thursday, October 22, 2015 in the Kebun Kelapa village, Secanggang Langkat District with lectured and discussion with "Suka Tani" farmer group partners. "Suka Tani" partners farmer group actively participate in training in the Community Development Programme and expected follow-up activity of community service within the next activity for the development of paddy farming farmer of "Suka Tani" group partners. "Suka Tani" farmers group could evaluate the feasibility of farming paddy through the analysis of the feasibility, when the feasibility of farming paddy by the partner farmer groups "Suka Tani" unfeasible, the 'Suka Tani " farmer groups may run business opportunity paddy seed as an alternative business opportunity and development "Suka Tani" partners farmer group through Community Development Programme will be continued in further programme about the introduction of business opportunity of seed paddy.
\end{abstract}

Keywords : Community Development, Feasibility, Paddy

\section{Pendahuluan}

Prioritas pembangunan sektor pertanian dewasa ini adalah melestarikan swasembada pangan, peningkatan ekspor nonmigas dan mengurangi pengeluaran devisa yang sekaligus memperluas lapangan kerja, meningkatkan kesejahteraan petani serta meningkatkan pertumbuhan ekonomi.

Sektor pertanian di Kabupaten Langkat merupakan salah satu potensi yang penting dalam memberikan kontribusi yang cukup besar terhadap Produk Domestik Regional Bruto (PDRB) Kabupaten Langkat. Produk Domestik Regional Bruto (PDRB) Kabupaten Langkat dan distribusi persentase Produk Domestik Regional Bruto (PDRB) Sektor Pertanian Kabupaten Langkat Atas Dasar Harga Konstan Tahun
2000 pada tahun 2013 masing-masing sebesar 54,04 \% (Badan Pusat Statistik Kabupaten Langkat, 2014).

Salah satu komoditas pertanian yang dikembangkan di Kabupaten Langkat adalah padi sawah. Luas panen, produksi dan rata-rata produksi padi sawah di Kabupaten Langkat adalah masingmasing $80289 \mathrm{Ha}, 467121$ ton dan 58,18 kw/ha (Badan Pusat Statistik Kabupaten Langkat, 2014). Salah satu kecamatan di Kabupaten Langkat adalah Kecamatan Secanggang. Produk Domestik Regional Bruto (PDRB) Kabupaten Langkat dan distribusi persentase Produk Domestik Regional Bruto (PDRB) Sektor Pertanian Kecamatan Secanggang Atas Dasar Harga Konstan Tahun 2000 pada tahun 2012 sebesar $64,98 \%$. 
Salah satu komoditas pertanian yang dikembangkan di Kecamatan Secanggang adalah padi sawah. Produksi padi sawah di Kecamatan Secanggang pada tahun 2013 adalah tertinggi dibanding tanaman pangan lainnya yakni 62551 ton dengan produktivitas sebesar 61,69 Kw/Ha dengan luas panen dan produktivitas masing-masing sebesar 10974 Ha dan 57 Kw/Ha. (Badan Pusat Statistik Kabupaten Langkat, 2014). Salah satu desa di kecamatan Secanggang adalah Desa Kepala Sungai. Kecamatan Secanggang.

Mitra dalam kegiatan Pengabdian kepada Masyarakat kepada masyarakat ini adalah Kelompok Tani "Suka Tani" di Desa Kepala Sungai Kecamatan Secanggang Kabupaten Langkat. Kelompok tani "Suka Tani” merupakan kelompok petani yang membudidayakan padi sawah. Padi sawah yang dibudidayakan adalah padi sawah tadah hujan yang masih tergantung pada iklim hujan.

Dalam kegiatan usahatani padi sawah, kelompok tani "Suka Tani" belum melakukan analisis kelayakan usahatani padi sawah yang telah mereka laksanakan sehingga petani kesulitan untuk melakukan evaluasi terhadap pengeluaran dan pendapatan usahatani. Hal ini akan menyebabkan petani pada kelompok tani "Suka Tani" kesulitan untuk menyusun perencanaan keuangan usahatani yang lebih baik dan mengacu hasi usahatani sebelumnya untuk usahatani yang akan dilaksanakan pada waktu yang akan datang apakah layak untuk direncanakan atau tidak. Ketidakpastian kelayakan usahatani tersebut akan menurunkan keuntungan usahatani yang dilakukan kelompok tani "Suka Tani".

Untuk meningkatkan keuntungan usahatani mitra kelompok tani "Suka Tani" maka mitra kelompok tani "Suka Tani" harus dapat menganalisis kelayakan usahatani yang telah dilaksanakan sehingga mitra kelompok tani "Suka Tani" dapat mengetahui distribusi kontribusi biaya produksi dan pendapatan dan mitra kelompok tani "Suka Tani" juga dapat mengetahui apakah usahatani padi sawah yang mereka laksanakan masih layak untuk dikembangkan atau tidak sehingga mitra kelompok tani "Suka Tani" dapat melaksanakan proses perencananaan usahatani pada masa yang akan datang.

\section{Target dan Luaran}

Target yang ingin dicapai dari kegiatan ini adalah: penyajian pemahaman tentang informasi konsep usahatani kelayakan usahatani padi pada mitra kelompok tani "Suka Tani" di Desa Kebun Kelapa Kecamatan Secanggang Kabupaten Langkat sehingga mitra kelompok tani "Suka Tani" dapat menerapkan analisis kelayakan usahani.

Luaran dalam pelaksanaan kegiatan ini adalah rekomendasi konsep analisis kelayakan usahatani padi sawah. Dengan demikian, petani padi sawah di Desa Kebun Kelapa Kecamatan Secanggang Kabupaten Langkat dapat menganalisis kelayakan usahatani padi sawah yang mereka laksanakan. Berdasarkan hasil analisis kelayakan usahatani padi sawah, petani dapat mengetahui kelayakan usahatani padi sawah. Apabila usahani padi sawah layak, mitra kelompok tani "Suka Tani" dapat mengembangkan usahatani padi sawah dengan nilai tambah yang lebih besar. Apabila usahatani padi sawah tidak layak, mitra kelompok tani "Suka Tani" dapat mengembangkan usahatani komoditas lainnya yang memiliki peluang bisnis dengan kelayakan usahatani yang lebih menguntungkan.

\section{Metode Pelaksanaan}

\section{Waktu, Tempat dan Mitra Pelaksana Pengabdian kepada Masyarakat}

Kegiatan Pengabdian kepada Masyarakat telah dilaksanakan pada Tanggal 22 Oktober 2015 di Desa Kebun Kelapa Kecamatan Secanggang Kabupaten Langkat. Mitra pelaksana Pengabdian kepada Masyarakat adalah kelompok tani "Suka Tani" yang terdiri dari petani padi sawah.

\section{Tim Pengabdian kepada Masyarakat}

Tim Pengabdian kepada Masyarakat merupakan dosen Program Studi Agribisnis Fakultas Pertanian Universitas Medan Area:

1. Endang Sari Simanullang, SP., M.Si

2. Faoeza Hafiz Saragih, SP., M.Sc

\section{Metode Pengabdian kepada Masyarakat}

Pelatihan dilaksanakan dengan menggunakan metode ceramah dan diskusi.

\section{Materi}

1. Potensi Tanaman Padi Sawah di Provinsi Sumatera Utara

2. Permasalahan dalam Upaya Peningkatan Produksi

3. Konsep Usahatani

4. Analisis Kelayakan Usahatani

5. Peluang bisnis penangkaran benih padi sawah

\section{Peserta}

Peserta kegiatan Pengabdian kepada Masyarakat terdiri dari para petani yang tergabung dalam mitra kelompok tani "Suka Tani", Kepala Desa Kebun Kelapa, Ketua P3A (Perkumpulan Petani Pemakai Air) Desa Kebun Kelapa, Penyuluh Pertanian dan Ketua Lembaga Pemberdayaan Masyarakat Desa Kebun Kelapa Kecamatan Secanggang Kabupaten Langkat dengan jumlah 40 orang.

\section{Hasil dan Pembahasan}

\section{Gambaran Umum Desa Kebun Kelapa Kecamatan Secanggang Kabupaten Langkat}

Desa Kebun Kelapa merupakan salah satu desa di Kecamatan Secanggang Kabupaten Langkat dengan luas wilayah yakni $7,5 \mathrm{Km}^{2}$. Jumlah penduduk adalah 2708 jiwa dengan jumlah rumahtangga yakni 667 rumahtangga. dengan rata-rata luas panen padi sawah adalah $680 \mathrm{Ha}$ dengan produksi 4202 Ton dengan luas lahan padi sawah yang digunakan secara keseluruhan untuk sawah tadah hujan.

Mitra kelompok tani "Suka Tani" memiliki luas lahan padi sawah yakni $30 \mathrm{Ha}$ yang dikelola oleh petani 
yang bekerjasama dengan pimpinan wilayah desa kebun kelapa, P3A (Perkumpulan Petani Pemakai Air), Lembaga Pemberdayaan Masyarakat dan Para Penyuluh Pertanian. Pada areal lahan padi sawah, telah tersedia jalan yang belum beraspal dan Mitra kelompok tani "Suka Tani" telah menjalankan program pipanisasi yakni pengairan padi sawah yang diatur oleh P3A (Perkumpulan Petani Pemakai Air).

\section{Kegiatan Pelatihan "Pengenalan Analisis Kelayakan Usahatani Padi Sawah di Desa Kebun Kelapa Kecamatan Secanggang Kabupaten Langkat”}

Uraian acara kegiatan pelatihan, diuraikan sebagai berikut:

1. Pembukaan

Kepala Desa sebagai pimpinan wilayah desa menyampaikan kata sambutan yakni menggambarkan kondisi, potensi dan program desa kebun kelapa yang terkait dengan padi sawah.

2. Penyajian Materi

Penyajian materi "Pengenalan Analisis Kelayakan Usahatani Padi Sawah di Desa Kebun Kelapa Kecamatan Secanggang Kabupaten Langkat" melalui metode ceramah oleh salah satu tim Pengabdian kepada Masyarakat.

Materi pelatihan yang disampaikan adalah pengenalan analisis kelayakan usahatani padi sawah di Desa Kebun Kelapa Kecamatan Secanggang Kabupaten Langkat adalah :

I. Potensi Padi Sawah di Provinsi Sumatera Utara

Potensi padi sawah terdiri dari potensi luas panen (Ha) dan produksi (Ton) dalam tiga wilayah yakni wilayah kecamatan secanggang, kabupaten langkat dan provinsi Sumatera Utara.

\section{Permasalahan dalam Upaya Peningkatan} Produksi

Partadiredja (2000), mendefinisikan produksi adalah segala kegiatan untuk menciptakan atau menambah manfaat atas suatu benda untuk memuaskan orang lain.

Kelemahan atau permasalahan yang dihadapi dalam upaya peningkatan produksi padi sawah yakni :

1. Biaya produksi semakin meningkat

2. Harga menurun

3. Pendapatan pelaku pertanian yang belum optimal

Kelemahan-kelemahan tersebut dapat dianalisis untuk mengetahui kelayakan usahatani padi sawah melalui analisis kelayakan usahatani. Evaluasi kelayakan usahatani merupakan salah satu solusi dalam peningkatan produksi. Berdasarkan hasil evaluasi kelayakan usahatani yakni layak atau tidak layak, pemberdayaan petani dan peluang bisnis melalui kelembagaan pertanian.

\section{Konsep Usahatani}

Untuk mengetahui tingkat pendapatan dan keuntungan yang diperoleh pelaku usaha dpertanian, perlu dilakukan analisis usahatani. Analisis usahatani adalah ilmu yang mempelajari bagaimana seseorang mengalokasikan faktor-faktor produksi yang ada, secara efektif dan efisien untuk tujuan memperoleh keuntungan pada waktu tertentu. Disebut efektif jika petani (produsen) dapat mengalokasikan sumberdaya yang mereka miliki dengan sebaik-baiknya, serta dikatakan efisien apabila pemanfaatan sumberdaya tersebut menghasilkan output yang melebihi input. Ruang Lingkup Usahatani, terdiri dari:

a. Faktor-faktor produksi/input

Merupakan sumberdaya yang digunakan dalam usahatani. Jenis-jenis faktor produksi yang digunakan dalam usahatani padi sawah :

1. Bibit/Benih

2. Pupuk

3. Pestisida

4. Tenaga Kerja

5. Dan lain-lain

b. Penerimaan usahatani

Gustiyana (2004), pendapatan dapat dibedakan menjadi dua yaitu pendapatan usaha tani dan pendapatan rumah tangga. Pendapatan merupakan pengurangan dari penerimaan dengan biaya total. Pendapatan rumah tangga yaitu pendapatan yang diperoleh dari kegiatan usaha tani ditambah dengan pendapatan yang berasal dari kegiatan diluar usaha tani. Pendapatan adalah hasil dari usaha tani, yaitu hasil kotor (bruto) dengan produksi yang dinilai dengan uang, kemudian dikurangi dengan baiaya produksi dan pemasaran sehingga diperoleh pendapatan bersih usaha tani (Mubyarto,2003). Penerimaan (revenue) adalah penerimaan dari hasil penjualan outputnya (Boediono, 2002).

Jumlah yang diterima petani dari suatu proses produksi, dimana penerimaan tersebut didapatkan dengan mengalikan produksi dengan harga yang berlaku saat itu.

Penerimaan usahatani penangkaran benih padi sawah $=$ Produksi x Harga

(Rupiah/Musim)x(Kg-Ton/Musim) Sukirno (2002). Biaya usahatani

Biaya usahatani/produksi adalah biaya yang dikeluarkan oleh seorang petani dalam proses produksi/usahatani.

Biaya produksi adalah semua faktor produksi yang digunakan, baik dalam bentuk benda maupun jasa selama produksi berlangsung. Biaya produksi adalah sebagai kompensasi yang diterima oleh para pemilik faktor-faktor produksi atau biaya-biaya yang dikeluarkan oleh petani dalam proses produksi, baik scara tunai maupun tidak tunai (Daniel, 2002).

Biaya usahatani terdiri dari : biaya tetap dan biaya variabel. Biaya tetap adalah biaya yang nilainya tidak dipengaruhi oleh besarnya produksi dan biaya variabel adalah biaya yang besarnya dipengaruhi oleh besarnya produksi.

Biaya usahatani $($ Rupiah $/ \mathrm{Ha} /$ musim $)=$ Biaya tetap $($ Rupiah/Ha/musim) $+\quad$ Biaya variabel

(Rupiah/Ha/musim)

Keuntungan usahatani

Keuntungan usahatani adalah selisih antara penerimaan dengan biaya usahatani. 
Keuntungan usahatani $(\mathrm{Rp} / \mathrm{Ha} / \mathrm{musim})=$ Penerimaan usahatani (Rp/Ha/musim) - Biaya usahatani (Rp/Ha/musim)

Mubyarto (2003)

IV. Analisis Kelayakan Usahatani

Analisis kelayakan usahatani adalah analisis yang digunakan untuk menilai kelayakan usahatani yang layak atau tidak untuk dikembangkan. Analisis Kelayakan Usahatani terdiri dari :

1. R/C ratio (Return Cost ratio)

Merupakan perbandingan antara penerimaan usahatani dan biaya usahatani.

$\mathrm{R} / \mathrm{C}$ Ratio $=\mathrm{R}$ atau Revenue atau Penerimaan Usahatani / C atau Cost atau Biaya usahatani

Harnanto (2003)

Kriteria Keputusan :

* R/C Ratio > 1, usahatani padi sawah layak dikembangkan.

* R/C Ratio < 1, usahatani padi sawah tidak layak dikembangkan.

* R/C Ratio = 1, usahatani padi sawah impas.

2. B/C Ratio (Benefit Cost Ratio)

Merupakan perbandingan antara keuntungan atau benefit usahatani dan Biaya Atau C/ Cost usahatani.

$\mathrm{B} / \mathrm{C}$ Ratio = B atau Benefit atau Keuntungan Usahatani / C atau Cost atau Biaya usahatani

Kriteria Keputusan :

* B/C Ratio > 1, usahatani padi sawah menguntungkan.

* B/C Ratio < 1, usahatani padi sawah rugi.

* B/C Ratio = 1, usahatani padi sawah impas.

V. Peluang Bisnis Penangkaran Benih Padi Sawah

Benih bermutu dan bersertifikat merupakan salah satu faktor produksi yang mempengaruhi keberhasilan dalam kegiatan produksi pada usahatani padi sawah. Apabila produksi padi sawah mengalami penurunan dan harga benih masih tinggi maka penerimaan usahatani akan menurun dan biaya usahatani akan meningkat. Hal tersebut akan menyebabkan penurunan keuntungan dan penurunan pendapatan petani padi sawah. Alternatif tekhnologi yang dapat meningkatkan keuntungan usahatani padi sawah adalah dengan melakukan penangkaran benih padi varietas unggul bersertifikat.

Peluang bisnis penangkaran benih padi sawah dapat menjadi solusi peluang bisnis apabila petani mengalami kerugian dalam menjalankan usahatani padi sawah. Studi Kasus : Petani Penangkar Benih Padi di Kelurahan Rorotan Jakarta Utara. Hasil pengkajian menunjukkan bahwa usaha penangkaran benih padi sangat menguntungkan dan dapat meningkatkan pendapatan petani. Keuntungan yang diperoleh dari usaha penangkaran benih padi adalah Rp. 9.953.320 dengan $\mathrm{R} / \mathrm{C}$ ratio 2,08. Berdasarkan tabel 1, diperoleh hasil analisis kelayakan usahatani pada penangkaran benih padi layak atau menguntungkan untuk dikembangkan dibandingkan padi sawah konsumsi.

Tabel 1. Perbandingan Analisis Usahatani Pada Penangkaran Benih Padi Sawah dan Padi Sawah Konsumsi

\begin{tabular}{|c|c|}
\hline $\begin{array}{l}\text { Penangkaran Benih } \\
\text { Padi Sawah }\end{array}$ & $\begin{array}{ll}\text { Padi } & \text { Sawah } \\
\text { Konsumsi } & \end{array}$ \\
\hline $\begin{array}{l}\text { Total Biaya } \\
\text { Usahatani : } \\
\text { Rp. } 9.171 .680\end{array}$ & $\begin{array}{l}\text { Total Biaya } \\
\text { Usahatani : } \\
\text { Rp. 7.477.680 }\end{array}$ \\
\hline $\begin{array}{l}\text { Total Penerimaan : } \\
(4.500 \mathrm{~kg} \text { GKP @ } \\
\operatorname{Rp} 4.250)=\mathrm{Rp} . \\
19.125 .000\end{array}$ & $\begin{array}{l}\text { Total Penerimaan : } \\
(6.500 \mathrm{~kg} \text { GKP @ } \\
\mathrm{Rp} 2.200) \quad= \\
\operatorname{Rp} .14 .300 .000\end{array}$ \\
\hline $\begin{array}{l}\text { Keuntungan dan } \\
\text { Kelayakan Usaha } \\
\text { Keuntungan : Rp. } \\
\text { 9.953.320 } \\
\text { R/C Ratio : } 2,08 \\
\text { B/C Ratio : } 1,08\end{array}$ & $\begin{array}{l}\text { Keuntungan dan } \\
\text { Kelayakan Usaha } \\
\text { Keuntungan : Rp. } \\
6.822 .320 \\
\text { R/C Ratio : } 1,91 \\
\text { B/C Ratio : } 0,91\end{array}$ \\
\hline
\end{tabular}

3.Diskusi (Tanya Jawab)

Diskusi (tanya jawab) dilakukan dua arah antara ketua dan anggota tim Pengabdian kepada Masyarakat dengan para petani yang tergabung dalam mitra kelompok tani “Suka Tani” yang kegiatan ini diarahkan oleh moderator (perwakilan petani mitra).

Pada acara diskusi/tanya jawab, para petani yang tergabung dalam mitra kelompok tani "Suka Tani" menanyakan tentang pembinaan yang terkait dengan pembinaan peluang bisnis penangkaran benih padi sawah, dan program ketahanan pangan yang terkait dengan penangkaran benih padi sawah serta strategi dalam menghadapi fluktuasi harga jual dan faktor produksi dalam usahatani padi sawah.

Tim Pengabdian kepada Masyarakat menjawab pertanyaan bahwa tim akan menindaklanjuti pembinaan peluang bisnis penangkaran benih padi sawah melalui kegiatan Pengabdian kepada Masyarakat tentang pengembangan peluang bisnis penangkaran padi sawah; peluang bisnis penangkaran benih padi sawah merupakan salah satu alternatif dalam pengembangan bisnis dan akan mendukung program ketahanan pangan; serta mitra kelompok tani "Suka Tani" dapat mengakses website kementerian pertanian untuk mengetahui informasi harga gabah dan mengembangkan penangkaran benih padi untuk menghasilkan benih padi yang dihasilkan sendiri tanpa dibeli sehingga dapat mengurangi peningkatan biaya produksi.

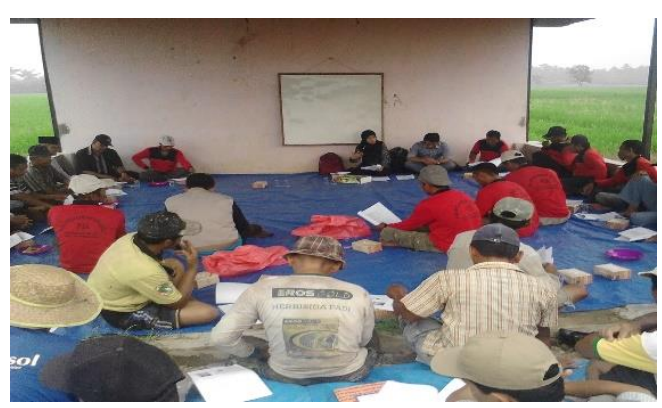

Gambar 1. Diskusi

(Tanya Jawab) 


\section{Penutup}

Penutup kegiatan Pengabdian kepada Masyarakat diakhiri dengan penyampaian kesan dan pesan oleh pimpinan kelompok tani atau desa dan moderator.

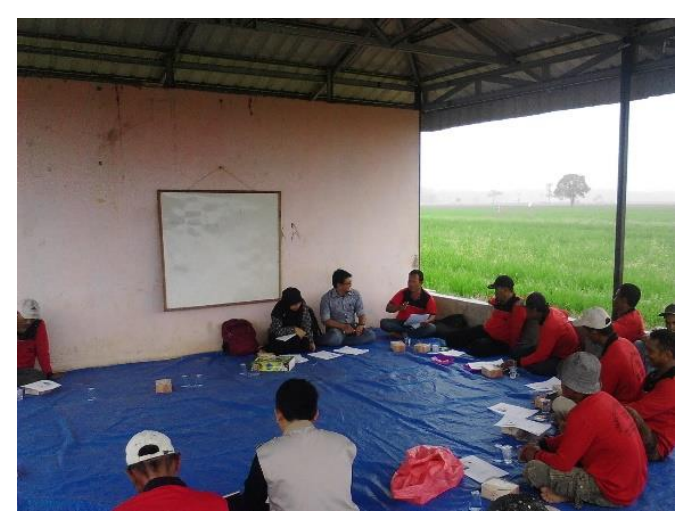

Gambar 2. Acara Penutupan

\section{Kesimpulan}

1. Kegiatan Pengabdian kepada Masyarakat telah dilaksanakan pada hari kamis tanggal 22 oktober 2015 di Desa Kebun Kelapa Kecamatan Secanggang Kabupaten Langkat.

2. Mitra kelompok tani "Suka Tani" berpartisipasi aktif dalam mengikuti pelatihan dalam kegiatan Pengabdian kepada Masyarakat dan mengharapkan tindak lanjut kegiatan Pengabdian kepada Masyarakat dalam kegiatan selanjutnya untuk pengembangan usahatani padi sawah mitra kelompok tani "Suka Tani".

3. Mitra kelompok tani "Suka Tani" dapat mengevaluasi kelayakan usahatani padi sawah melalui analisis kelayakan usahatani sehingga dapat mengambil keputusan untuk mengembangkan usahatani padi sawah dengan skala usaha yang lebih besar.

4. Apabila kelayakan usahatani padi sawah yang dikembangkan oleh mitra kelompok tani "Suka Tani" tidak layak untuk dikembangkan, maka mitra kelompok tani 'Suka Tani' dapat mengusahakan peluang bisnis penangkaran benih padi sawah sebagai alternatif peluang bisnis.

5. Pembinaan mitra kelompok tani "Suka Tani" melalui kegiatan Pengabdian kepada Masyarakat akan dilanjutkan dalam kegiatan selanjutnya mengenai pengenalan peluang bisnis penangkaran benih padi sawah.

\section{Daftar Pustaka}

Badan Pusat Statistik Kabupaten Langkat. 2014. Langkat dalam Angka Tahun 2014. Badan Pusat Statistik Kabupaten Langkat. Stabat.

Boediono. 2002. Pengantar ilmu ekonomi, no. 1 (Ekonomi Mikro ). BPFE, Yogyakarta.
Daniel, M. 2002. Pengantar ekonomi pertanian. Bumi Aksara. Jakarta.

Gustiyana, H. 2004. Analisis Pendapatan Usahatani untuk Produk Pertanian. Salemba empat: Jakarta

Hernanto, F. 2003. Ilmu usaha tani. Peneber swadaya. Jakarta.

Mubyarto. 2003. Pengantar ekonomi pertanian. LP3ES. Jakarta

Partadiredja, A. 2000. Pengantar ekonomi. BPFE. Jakarta 